\title{
Spread of seafish invasions in the northen sea of okhotsk as a factor of human infection
}

\author{
E.A. Vitomskova*, and V.I. Zhuleva \\ Federal state budgetary scientific institution Magadan Research Institute of Agriculture Russian \\ Federation, Magadan, Russia
}

\begin{abstract}
The results of the analysis are presented in the comparative aspect of the long-term - 1989 - 2021. - dynamics of infection of commercial fish with parasites common to humans and animals, and determination of their role in the spread of invasions among the population of the region. During this period, in marine fish - herring Clupea pallasii Valenciennes, 1847 (Clupeiformes: Clupeidae), saffron cod Eleginus gracilis, flounder Acanthopsetta nadeshnyi and smelt Osmerus mordax dentex Steindachner, 1870 - 5 types of helminthes potentially dangerous for humans have been identified, which can cause such dangerous diseases like anisacidosis, diphyllobothriasis and corynosomiasis. All fish species show high rates of invasion. Herring is infested by $97.4 \%$, saffron cod $-55.2 \%$, flounder $-67.5 \%$, smelt $-58.4 \%$. Ichthyopathological examinations isolated Anisakis simplex, Pseudoterranova decipiens, Pyramicocephalus phocarum, Diphyllobothrium sobolevi, Corynosoma strumosum. Individuals with combined invasion were registered: saffron cod Anisakis simplex, Pyramicocephalus phocarum, Corynosoma strumosum; smelt Anisakis simplex (Pseudoterranova decipiens), Diphyllobothrium sobolevi, Corynosoma strumosum. The most dangerous for humans are flounder and smelt due to the localization of helminths in the muscles.
\end{abstract}

\section{Introduction}

Fishing takes one of the main places in the economy of the Far Eastern region of Russia, including its northern part within the boundaries of the Sea of Okhotsk basin. Fish of various breeds are caught on an industrial scale and by the local population for personal consumption all year round.

Fish has long been an important source of meeting the needs of the population in protein food and other elements of water origin, which are absent in livestock products, and affordable food in the conditions of the Magadan region.

The consumption of fish must meet certain safety criteria. Nowadays, the quality of the fish caught and sold can only meet organoleptic indicators and have no information about the parasitological situation. Timely parasitological control, correct identification of the pathogens identified in fish and the lesions caused by them allow not only to avoid

${ }^{*}$ Corresponding author: ekaterinaseymchan@mail.ru 
unreasonable fears about the quality of fish, but also to pay attention to such infection that can cause rejection of fish raw materials or products made from it. So, the issue of ensuring the quality and safety of fish products for human health in terms of parasitic purity has a certain novelty and undoubted relevance. Determination of the impact of fish diseases on the health of the population with the determination of the risk of exposure and risk management in the aspect of its minimization is of a practical nature, has economic and social significance.

Long-term epizootic monitoring of water bodies in the North-East of Russia is the main factor of supporting the economic stability of the fishing industry and allows predicting the situation for the future. The leading place in the fight against the spread of helminthiasis of fish dangerous for humans is taken by preventive sanitary-hygienic and veterinary-sanitary measures.

Invasive diseases are widespread and can cause significant economic damage to fish farming. Some of them cause disease and mass death of fish, while others are dangerous for humans [1].

The study of parasitic diseases of fish in the Magadan region is the subject of the works of A.M. Serdyukov, who studied all types of commercial fish in mass quantities and over a long period of time. In the studied individuals, larval anisacidosis was recorded $[2,3]$. In the foreign literature, cases of anisakidosis in humans are also mentioned. With gastric localization of anisakid larvae (the most common form of the disease), severe epigastric pain, nausea, and vomiting occur. In some cases, the disease is accompanied by fever $[4,5]$. Investigating the species identity of diphyllobothriids in the northern Sea of Okhotsk was carried out by A.M. Serdyukov [6]. E.V. Belous first discovered plerocercoid and diphyllobothriids in smelt (Hypomesusolidus) in Primorsky Krai and proved their epidemiological and epizootic significance. A new species of diphyllobothriids was named as Diphyllobothrium sobolevi, Belous, 1953 [7].

The wide spread and high degree of invasion by acanthellae acanthocephalus Corynosoma strumosum was noted in most species of commercial fish in the Magadan region $[8,9]$.

The aim of this work was to identify and study parasites of fish in the northern Okhotsk region, which are of great epidemiological significance.

\section{Materials and methods}

The material was collected for the period from 1989 to 2021 during 27 expedition trips to the Ola, North-Evensk districts of the Magadan region. When studying the helminth fauna of commercial fish, the objects of studying were four types of fish: herring Clupea pallasii, saffron cod Eleginus gracilis, flounder Acanthopsettanadeshnyi and smelt Osmerus mordax dentex. By the method of incomplete helminthological autopsy [10], 3585 specimens of commercial fish were studied.

In fish, the skin, abdominal cavity, gills, and internal organs were carefully examined. After visual inspection of the surface of the internal organs, they were subjected to layering, followed by compression and viewing into light with the naked eye and with the help of optical means. The study of helminth larvae was carried out both in a live and in a fixed state on total preparations. Helminths were grouped according to their systematic affiliation. The plerocercoids of cestodes were stained with alum carmine, nematode larvae were cleared in lactic acid, and acanthellae were cleared in glycerin. 


\section{Results and discussion}

As a result of the study, it was established that in the Northern sea of Okhotsk during the period of ichthyopathological studies in four species of marine commercial fish, five causative agents of invasions were registered. Anisakis simplex, Pseudoterranova decipiens, Pyramicocephalus phocarum, Diphyllobothrium sobolevi, Corynosoma strumosum.

Individuals with combined invasion were registered: saffron cod Anisakis simplex, Pyramicocephalus phocarum, Corynosoma strumosum; flounder Anisakis simplex (Pseudoterranova decipiens), Corynosoma strumosum; smelt Anisakis simplex (Pseudoterranova decipiens), Diphyllobothrium sobolevi, Corynosoma strumosum. And only one species of helminths - Anisakis simplex was found in Pacific herring.

The infestation of the studied fish species with larvae of Anisakissimplex and Pseudoterranova decipiens reaches high values for all years of fishing (Table 1). The highest rates are observed in Pacific herring 97,4 \%, at the intensity of invasion - 1$49(5,0) \pm 1,84$; in saffron cod and smelt - at about the same level 45,3 $(1-34(7,0) \pm 2,77)$ and $40,8(1-5(1,7) \pm 0,24)$ respectively. In flounder, the same indicators, on average, were slightly higher - $66,4(1-24(4,0) \pm 1,14)$.

Significant fluctuations in the infection rates of commercial fish are noted not only at the interspecific, but also at the intraspecific level. So, the intensity of herring invasion in all years of the fishery was approximately the same and ranged from $80.0 \%$ to $100.0 \%$. Only in 1990 in the herring caught in the Gizhiginskaya Bay of the North-Evensk district, it was $51.7 \%$. Infestation of saffron cod with anisakid larvae on average was $45.3 \%$, with a deviation of this indicator from $9.3 \%$ (1996) to 77.0 (1991).

In flounder, the infection with the combined invasion of Anisakis simplex (Pseudoterranova decipiens), varied from 52.9\% to 86.7\%; and only in 1997 the indicator dropped to the minimum value $-9.6 \%$.

Table 1. Infection of commercial fish species with larvae of the genus Anisakis.

\begin{tabular}{|c|c|c|c|c|c|c|c|c|}
\hline \multirow[t]{2}{*}{ Fish name } & \multirow[b]{2}{*}{$\begin{array}{l}\text { Exami } \\
\text { ned } \\
\text { speci- } \\
\text { mens }\end{array}$} & \multicolumn{2}{|c|}{ Infested } & \multirow[b]{2}{*}{$\begin{array}{c}\text { I.I.* } \\
\text { limits } \\
\text { (average) } \\
\mathrm{M} \pm \mathrm{m}\end{array}$} & \multirow{2}{*}{$\begin{array}{l}\text { Total } \\
\text { larva-e }\end{array}$} & \multicolumn{3}{|c|}{ Including } \\
\hline & & $\begin{array}{l}\text { Spe- } \\
\text { cim- } \\
\text { ens }\end{array}$ & $\%$ & & & $\begin{array}{l}\text { in the } \\
\text { body } \\
\text { cavity, } \\
\%\end{array}$ & $\begin{array}{l}\text { on } \\
\text { inter- } \\
\text { nal } \\
\text { organs } \\
, \%\end{array}$ & $\begin{array}{l}\text { Mus- } \\
\text { cles, } \\
\%\end{array}$ \\
\hline $\begin{array}{l}\text { Herring (Clupea } \\
\text { pallasii Valenciennes) }\end{array}$ & 2045 & 1992 & 97,4 & $1-49(5,0) \pm 1,84$ & 9978 & 36,0 & 64,0 & - \\
\hline $\begin{array}{l}\text { saffron cod (Eleginus } \\
\text { gracilis) }\end{array}$ & 497 & 225 & 45,3 & $1-34(7,0) \pm 2,77$ & 1748 & 24,0 & 76,0 & - \\
\hline $\begin{array}{l}\text { flounder } \\
\text { (Acanthopsetta nadesh } \\
\text { nyi) }\end{array}$ & 678 & 450 & 66,4 & $1-24(4,0) \pm 1,14$ & 1868 & 55,0 & 34,0 & 11,0 \\
\hline $\begin{array}{l}\text { smelt Osmerus mordax } \\
\text { dentex) }\end{array}$ & 355 & 145 & 40,8 & $1-5(1,7) \pm 0,24$ & 249 & 19,2 & 26,1 & 54,7 \\
\hline In total: & 3585 & & & & & & & \\
\hline
\end{tabular}

Note:*I.I. (intensity of invasion) - the number of larvae recorded in one infected fish.

In smelt, a similar mixed invasion was - 24.0\% - 51.4\% (1990.1996); and only in 2021 its maximum value was designated $72.0 \%$. The issue of the spread of anisakid larvae in the fish body is of great epidemiological importance. So, in Pacific herring and saffron cod, the larvae are located exclusively in the body cavity and on the internal organs. Figure 3 clearly shows that Anisakis simplex larvae are located in the body cavity of the Pacific herring, Clupea pallasii in significant numbers are in thin-walled capsules. 
In flounder and smelt, the larvae penetrate into the abdominal muscles and muscles of the back and their infection ranges from $11.0 \%$ to $54.7 \%$, respectively. In flounder, Anisakis simplex larvae found on internal organs (liver, milt, eggs, pyloric appendages, spleen, intestinal mesentery) were in thin-walled capsules, and in the body cavity and in the abdominal muscles - in a free state without capsules. The larvae of Pseudoterranova decipiens were located in the muscles of the back in well-defined capsules, but their largest number (about 1/3) was recorded in the body cavity in a capsule-free state.

\section{Dynamics of fish infestation with anisakid larvae}

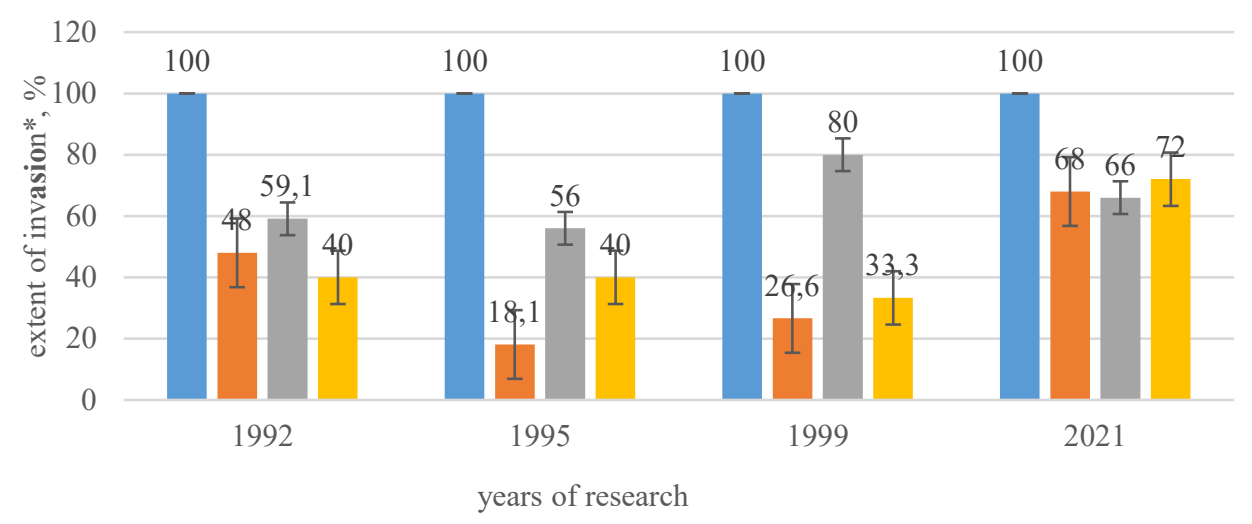

- herring $\quad$ saffron cod $\square$ flounder $\square$ smelt

Note:* E.I. (extent of invasion) - percentage of fish infestation.

Fig. 1. Dynamics of fish infestation with anisakid larvae.

The analysis of the dynamics of infestation of the above fish species with anisakid larvae did not reveal significant features and patterns (Figure 1). However, the extent of herring invasion over a long time period $(1992$ - 2021) was determined and amounted to $100.0 \%$. The values of the indicators of the infestation in saffron cod and flounder varied over the years of the research from $33.3 \%$ to $68.0 \%$, and only in 1999 amounted to $80.0 \%$. Of high interest is the fact that the extent of the invasion of smelt Osmerus eperlanus dentex in all the years of the research was approximately at the same level: $1990-24.0 \%, 1992-40.0 \%$, $1995-40.0 \%, 1996-51.4 \%, 1997-31.2 \%, 1998-36.0 \%, 1999-33.3 \%$ and only in 2021 significantly exceeded the same indicators and was $72.0 \%$.

Table 2. Infestation of smelt and saffron cod with plerocercoids of genus Diphyllobothrium and Pyramicocephalus.

\begin{tabular}{|c|c|c|c|c|c|c|c|c|}
\hline \multirow[t]{2}{*}{ Fish name } & \multirow[b]{2}{*}{$\begin{array}{l}\text { Exam } \\
\text { ined } \\
\text { speci- } \\
\text { mens }\end{array}$} & \multicolumn{2}{|c|}{ Infested } & \multirow{2}{*}{$\begin{array}{c}\text { I.I.* } \\
\text { limits } \\
\text { (average) } \\
\mathrm{M} \pm \mathrm{m}\end{array}$} & \multirow{2}{*}{$\begin{array}{l}\text { Total } \\
\text { larva- } \\
\text { e }\end{array}$} & \multicolumn{3}{|c|}{ Including } \\
\hline & & $\begin{array}{c}\text { Sp- } \\
\text { cim- } \\
\text { ens }\end{array}$ & $\%$ & & & $\begin{array}{c}\text { in the } \\
\text { body } \\
\text { cavity, } \\
\%\end{array}$ & $\begin{array}{c}\text { on } \\
\text { inter- } \\
\text { nal } \\
\text { organs, } \\
\%\end{array}$ & $\begin{array}{c}\text { Mus- } \\
\text { cles, } \\
\%\end{array}$ \\
\hline $\begin{array}{c}\text { Pyramicocephalus } \\
\text { phocarum }\end{array}$ & & & & & & & & \\
\hline
\end{tabular}




\begin{tabular}{|c|c|c|c|c|c|c|c|c|}
\hline $\begin{array}{l}\text { saffron cod } \\
\text { (Eleginus gracilis) }\end{array}$ & 533 & 317 & 59,8 & $1-25(7,1) \pm 2,7$ & 2269 & 36,2 & 63,8 & - \\
\hline $\begin{array}{c}\text { Diphyllobothrium } \\
\text { sobolevi }\end{array}$ & \multicolumn{7}{|l|l|}{} & \\
\hline $\begin{array}{l}\text { smelt (Osmerus } \\
\text { mordax dentex) }\end{array}$ & 313 & 203 & 64,8 & $1-12(4,9) \pm 1,36$ & 990 & 15,1 & 84,9 & - \\
\hline In total: & 846 & & & & & & & \\
\hline
\end{tabular}

Note:* I.I. (intensity of invasion) - the number of larvae recorded in one infected fish.

During the analyzed period, the diphyllobothriidae plerocercoids Pyramicocephalus phocarum were found in $59.8 \%$ of the studied individuals of the saffron cod (Table 2 ). The intensity of invasion varied from 1 to 25 (on average, 7.1). Helminths were localized in the body cavity of the fish and on the internal organs without capsules. The muscles of the saffron cod remained free of plerocercoids. Smelt infestation rates, in comparison with saffron cod, turned out to be slightly higher $-64.8 \%$.

The diphyllobothriidae plerocercoids were located in the body cavity of the fish and on the internal organs exclusively in an encapsulated state. We did not find plerocercoids of the tapeworm D.sobolevi in any of the dissected smelts in the muscles of the body.

It should be noted that we have discovered for the first time the plerocercoids of D.soboleviy in smelt Osmerus eperlanus dentex of the North Okhotsk populations.

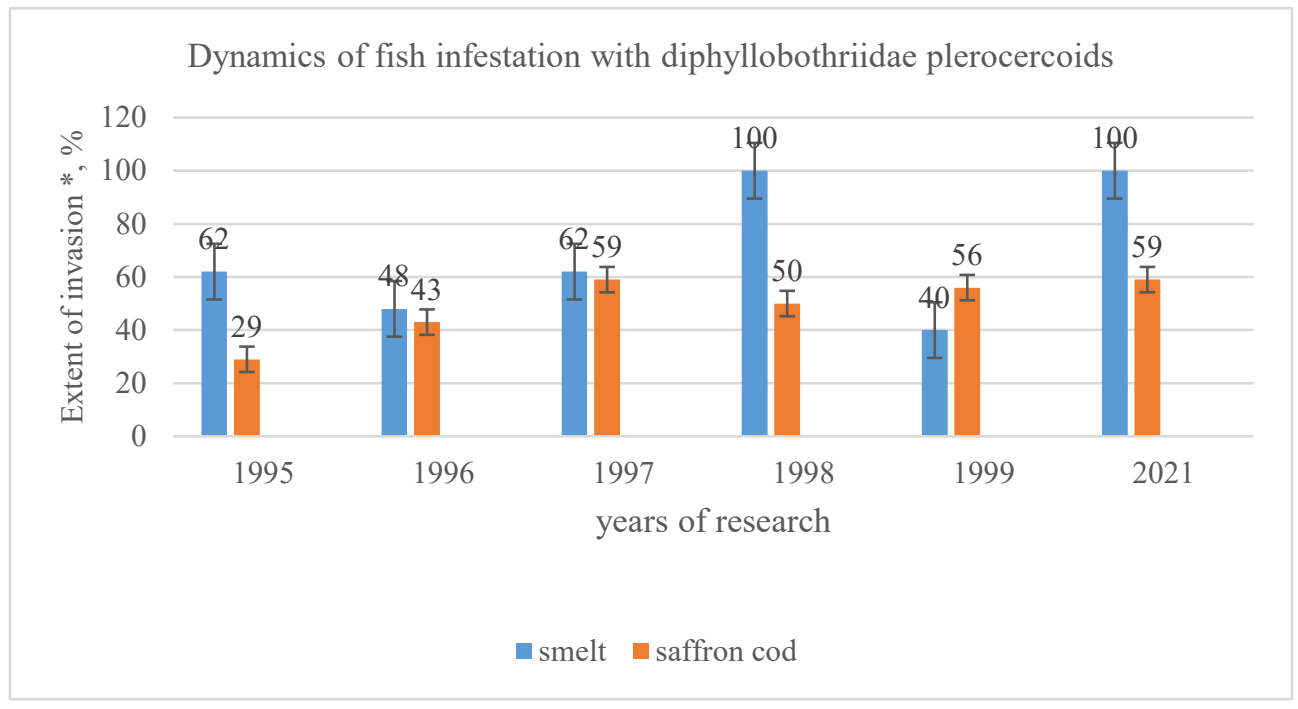

Fig. 2. Dynamics of fish infestation with diphyllobothriidae plerocercoids.

The dynamics of the extent of invasion by diphyllobothriidae plerocercoids of smelt and saffron cod over the analyzed period of time turned out to be without significant fluctuations (Figure 2), with the exception of 2021, when there was a simultaneous increase in indicators in both fish species (100, \% and 59.0\%).

Acanthellae of spiny-headed worms Corynosoma strumosum were found in $47.4 \%$ of the saffron cod, with an intensity of invasion from 8 to 181 (on average 44.7) larvae per one infested individual.

The infestation of smelt Osmerus eperlanus dentex with acanthellae of spiny-headed worms Corynosoma strumosum for the whole period of research reaches high values $95.8 \%$, with a deviation of this indicator from $84.0 \%$ to $100.0 \%$. The overall average indicator of the intensity of invasion was 10-184 (on average 49.0) specimens of larvae per 
one infested individual. All acanthellae found in the body cavity and on internal organs (liver, gonads, under the intestinal mucosa) were found only in capsules in saffron cod and smelt.

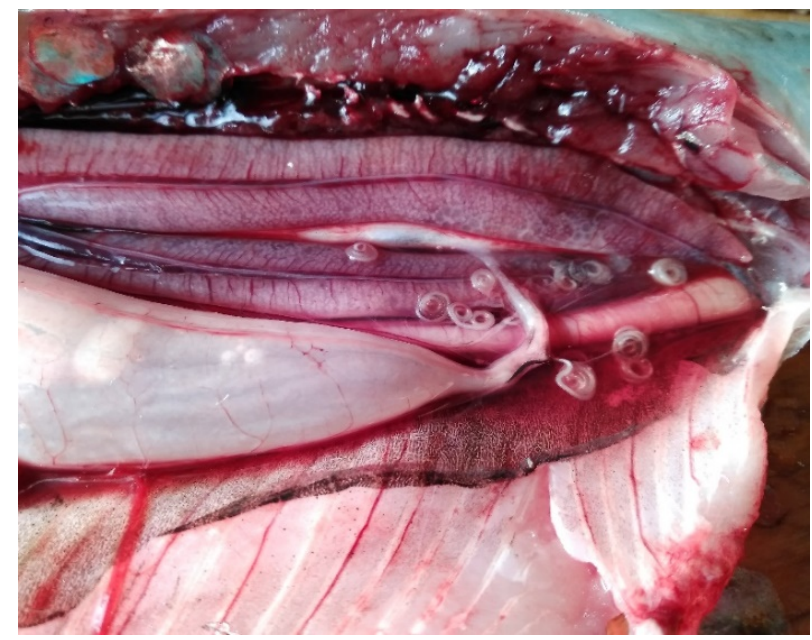

Fig. 3. Larvae of Anisakis simplex in the body cavity of the Pacific herring Clupea pallasii.

\section{Conclusions}

While ichthyopathological studies in marine fish species: herring Clupea pallasii, saffron cod Eleginus gracilis, flounder Acanthopsetta nadeshnyi and smelt Osmerus mordax dentex the Northern sea of Okhotsk, five types of helminths potentially dangerous to humans were registered: Anisakis simplex, Pseudoterranova decipiens, Pyramicocephalus phocarum, Diphyllobothrium sobolevi, Corynosoma strumosum. All fish species have a high degree of invasion (E.I.,\%): herring - 91.2\%, saffron cod - 55.2\%, flounder $-60, \%$, smelt - 58.4\%. High rates of fish infestation with combined invasions were recorded: saffron cod Anisakis simplex, Pyramicocephalus phocarum, Corynosoma strumosum; flounder Anisakis simplex (Pseudoterranova decipiens), Corynosoma strumosum; smelt Anisakis simplex (Pseudoterranova decipiens), Diphyllobothrium sobolevi, Corynosoma strumosum. The most dangerous for human health were flounder Acanthopsetta nadeshnyi and smelt Osmerus mordax dentex, as the helminths were located in the thickness of the muscles of the studied fish species. All the reservoirs where samples were taken for ichthyopathological research were recognized as unfavorable for helminthic invasions. To reduce the risk of transmission of invasions through marine commercial fish, humans need to follow the veterinary and sanitary examination of fish and fish products during their catch, processing and selling.

\section{References}

1. C. Foti, M. Fanelli, V. Mastrandrea, R. Buquicchio, N. Cassano, A. Conserva, E. Nettis, J. Immunopathol. Pharmacol 4, 847-851 (2006)

2. A.M. Serdyukov, Medical parasitology 2, 50-54 (1993)

3. A.M. Serdyukov, E.A. Vitomskova, E.A. Zaikova, G.R. Islamgaleeva, Epizootic state of diseases of salmonids of the genus Oncorhynchus in the northern part of the Sea of 
Okhotsk, Agriculture of the North at the turn of the millennium, 242-247 (Magadan, 2004)

4. M.E.A Wilson, World Guide to Infections. Diseases, Distribution, Diagnosis, 433-434 (New York: Oxford University Press, 1991)

5. V.V. Gorokhov, V.P. Sergiev, N.A. Romanenko, Anisakidosis as a growing environmental and social problem, 50-54 (Medical parasitology, 1998)

6. A.M. Serdyukov, Diphyllobothriidae of Western Siberia, 120 (Novosibirsk: Science, 1979)

7. E.V. Belous, Parasitic worms of freshwater vertebrates of Primorsky Krai, 22 (Moscow, 1953)

8. E.A. Vitomskova, Helminths of commercial fish of northen Okhotsk region, dangerous for humans and animals, 7-11 (Moscow, 2000)

9. K.A. Vitomskova, Helmintos the Producer Co-operative Food-Fish Organization of the Nothern Part of Okhotsk Sea Basin, which are dangerous for the human beings and animals, 132 (Magadan: NEMARI RAAS, 2003)

10. T.Ye. Butorina, Determinant of the most common fish parasites in the Far Eastern seas, 115 (Vladivostok, 1997) 